\title{
Occurrence and Chemistry of Cell Wall Teichoic Acids in the Genus Brevibacterium
}

\author{
By F. FIEDLER* AND A. BUDE \\ Institut für Genetik und Mikrobiologie der Universität München, Maria-Ward-Str. Ia, \\ 8000 München 19, FRG
}

(Received 23 March 1989; revised 31 July 1989; accepted 4 August 1989)

\begin{abstract}
The cell walls of Brevibacterium casei NCDO 2048, B. epidermidis NCDO 2286 and 14 B. linens isolates from cheese were shown to contain teichoic acids as the dominant non-peptidoglycan polymers. The variation in teichoic acid composition was similar to that described earlier for $B$. linens strains and for B. iodinum. In B. casei NCDO 2048 a glycerol teichoic acid was found, whereas in $B$. epidermidis NCDO 2286 glycerol teichoic acid existed together with mannitol teichoic acid. The occurrence of teichoic acids in the cell walls of all Brevibacterium strains investigated constitutes a biochemical characteristic of the genus and is of chemotaxonomic relevance. The co-existence of glycerol and mannitol within the cell walls of the $B$. linens strains AC480 and AC577 was investigated in detail. The polyols belonged to separate polymers: a glycerol teichoic acid and a mannitol teichoic acid.
\end{abstract}

\section{INTRODUCTION}

The classification of the genus Brevibacterium was uncertain for decades. First proposed by Breed (1953) for several non-sporeforming Gram-positive rods, with Brevibacterium linens as the type species, the genus soon became the depository for bacteria that exhibited a variety of morphological, physiological and biochemical features (Breed, 1957). In the years following, a series of numerical taxonomic (Da Silva \& Holt, 1965; Davis \& Newton, 1969; Bousfield, 1972; Jones, 1975; Seiler et al., 1977), physiological, biochemical and genetic studies (Fiedler et al., 1970; Yamada and Komagata, 1970, 1972; Keddie \& Cure, 1977; Collins et al., 1979; Stackebrandt \& Fiedler, 1979; Stackebrandt et al., 1980) clearly showed the heterogeneity of the genus Brevibacterium. Furthermore, the data indicated that $B$. linens was distinct from Arthrobacter globiformis and constituted the nucleus of a redefined genus Brevibacterium. This was supported both by nucleic acid association (Crombach, 1974) and 16S-rRNA cataloguing studies (Stackebrandt et al., 1980; Stackebrandt \& Woese, 1981).

As a consequence of these investigations the genus Brevibacterium was redefined (Collins $e t$ al., 1980). The essential features are: the presence of meso-diaminopimelic acid in the cell-wall peptidoglycan; the absence of arabinogalactan and mycolic acids in the cell wall; the occurrence of major amounts of dihydrogenated menaquinones with $\mathrm{MK} 8\left(\mathrm{H}_{2}\right)$ or $\mathrm{MK} 8\left(\mathrm{H}_{2}\right)$ and $\mathrm{MK} 7\left(\mathrm{H}_{2}\right)$; and DNA with a mol \% G $+\mathrm{C}$ of $60-70\left(T_{\mathrm{m}}\right)$. In addition to these characteristics, the presence of teichoic acids in the cell wall of $B$. linens (Fiedler et al., 1981) and of $B$. iodinum (Anderton \& Wilkinson, 1980) was suggested as an additional chemotaxonomic marker for the genus (Fiedler et al., 1981). This marker was not investigated in detail for the new species $B$. casei and $B$. epidermidis (Collins et al., 1983) but preliminary data provided evidence for the existence of a glycerol teichoic acid in the cell wall of B. epidermidis strain 2285 (Anderton \& Wilkinson, 1985). In order to examine the coherence of Brevibacterium with respect to the occurrence of cell wall teichoic acids we have studied one strain of each of these new species and several new isolates from the surface of cheese (Seiler, 1986). The indication that in certain strains of Brevibacterium 
a glycerol teichoic acid may occur simultaneously with a ribitol teichoic acid or a mannitol teichoic acid (Anderton \& Wilkinson, 1980; Fiedler et al., 1981) was also investigated in detail.

\section{METHODS}

Bacteria and their cultivation. The strains used were: B. casei NCDO 2048 and B. epidermidis NCDO 2286 (NCDO: National Collection of Dairy Organisms, Shinfield. UK); B. linens AC480 and AC577 (obtained from Dr W. H. J. Crombach, Microbiology Laboratory, Agricultural University of Wageningen, The Netherlands); and $14 \mathrm{~B}$. linens isolates from various cheeses from different dairies in Germany, France, Denmark and Switzerland (Seiler, 1986). These dairy isolates were kindly supplied by Dr H. Seiler, Dairy Research Institute of Weihenstephan, Freising, FRG. The organisms were grown with aeration by shaking in a medium containing $1 \%$ peptone (Oxoid), $0.5 \%$ glucose, $0.5 \%$ yeast extract (Oxoid) and $0.5 \% \mathrm{NaCl}$ at $30^{\circ} \mathrm{C}$. Cultures were checked for purity by phase-contrast microscopy and plating on the above medium solidified with $1 \%$ agar (Oxoid).

Isolation of cell walls. Bacteria were grown in 3 litres of medium to early stationary phase. Cells were harvested by centrifugation $(20000 \mathrm{~g}, 20 \mathrm{~min})$ and heated at $100^{\circ} \mathrm{C}$ for $15 \mathrm{~min}$. Cell walls were then prepared as described by Schleifer \& Kandler (1967).

Isolation of teichoic acids and teichoic-acid-linked glycopeptides. Teichoic acids were extracted from cell walls with $0.025 \mathrm{M}$-glycine $/ \mathrm{HCl}, \mathrm{pH} 2 \cdot 5$, at $100^{\circ} \mathrm{C}$ for $10 \mathrm{~min}\left(5 \mathrm{mg}\right.$ cell wall $\mathrm{ml}^{-1}$ ) (Kaya et al., 1985). After cooling, the incubation mixture was centrifuged at $48000 \mathrm{~g}$ for $20 \mathrm{~min}$ and the sediment re-extracted in the same way. Supernatants were combined, dialysed against deionized water, and lyophilized. For the preparation of teichoicacid-linked glycopeptides $200 \mathrm{mg}$ cell wall was carefully homogenized in $20 \mathrm{ml} 0.01 \mathrm{M}$-ammonium acetate, $\mathrm{pH} 6.8$, and incubated with $100 \mathrm{mg}$ lysozyme at $27^{\circ} \mathrm{C}$ for $6 \mathrm{~h}$. After centrifugation at $48000 \mathrm{~g}$ for $20 \mathrm{~min}$ the supernatant was dialysed against deionized water and lyophilized. The teichoic-acid-linked glycopeptides $(12 \mu \mathrm{mol}$ phosphorus) were treated with $N$-acetylmuramyl-(L-alanine)-amidase for $24 \mathrm{~h}$ at $37^{\circ} \mathrm{C}$ in $50 \mathrm{~mm}$-Tris/ $\mathrm{HCl}$, $5 \mathrm{mM}-\mathrm{MgCl}_{2}, 0.02 \%$ sodium azide, $\mathrm{pH} 7.9$. The amidase used was isolated from human serum (Mollner $\&$ Braun, 1984) and was a gift from Dr J.-V. Höltje, Max-Planck Institut für Entwicklungsbiologie, Tübingen, FRG.

Hydrolysis with hydrofuoric acid $(H F)$. Dried cell walls, and lyophilized teichoic acids and teichoic-acid-linked glycopeptides were treated with $60 \%(\mathrm{w} / \mathrm{v})$ aqueous HF (Riedel-de Haen, Seelze, FRG) as described by Anderson et al. (1977). The incubation was done in polyethylene tubes at $4{ }^{\circ} \mathrm{C}$ for $16 \mathrm{~h}$. HF was volatilized in vacuo over $\mathrm{NaOH}$ pellets in a glass-free system.

Smith degradation. Teichoic acids (50-100 $\mu$ mol phosphorus) were oxidized with $0.1 \mathrm{M}$-sodium periodate in $0.5 \mathrm{ml} 0.1 \mathrm{M}$-sodium acetate, $\mathrm{pH} 5$, in the dark at $4{ }^{\circ} \mathrm{C}$ for $96 \mathrm{~h}$ according to Kojima et al. (1985). After passage through a small column of Dowex $50-\mathrm{H}^{+}$the oxidized material was analysed by gel-filtration chromatography.

Deacylation of cardiolipin. Cardiolipin from bovine heart (Sigma) was deacylated by the method described for lipoteichoic acid by Koch \& Fischer (1978).

Column chromatography. Ion-exchange chromatography was done on a column $(18 \times 30 \mathrm{~cm})$ of DEAE-Sephacel (Pharmacia) equilibrated with $5 \mathrm{mM}-\mathrm{Tris} / \mathrm{HCl}, \mathrm{pH} 7 \cdot 2$, and eluted with a linear gradient of 0 to $1 \mathrm{M}-\mathrm{NaCl}$ in equilibration buffer at a flow rate of $20 \mathrm{ml} \mathrm{h}^{-1}$. For gel-filtration chromatography the following columns and conditions were used: (1) $1.5 \times 90 \mathrm{~cm}$ Bio-Gel P2 (Bio-Rad), eluted with distilled water at $30 \mathrm{ml} \mathrm{h}^{-1}$; (2) $2.5 \times 145 \mathrm{~cm}$ Sephacryl S-300 (Pharmacia), eluted with $0.1 \mathrm{M}$-ammonium acetate, $\mathrm{pH} \mathrm{6.7}$, at $25 \mathrm{ml} \mathrm{h}^{-1}$; (3) $1.6 \times 100 \mathrm{~cm}$ Sephadex G-25 (Pharmacia), eluted with $0.1 \mathrm{M}$-ammonium acetate, pH 6.7, at $25 \mathrm{ml} \mathrm{h}^{-1}$. (4) $1.6 \times 100 \mathrm{~cm}$ Sepharose 6B-CL (Pharmacia), eluted with $0.1 \mathrm{M}$-ammonium acetate, $\mathrm{pH} \mathrm{6.9}$, at $15 \mathrm{ml} \mathrm{h}^{-1}$. The columns were run at room-temperature. Affinity chromatography was done using a small column (Pasteur pipette) of ConA-Sepharose (Pharmacia). The column was equilibrated with $0.1 \mathrm{M}-\mathrm{Tris} / \mathrm{HCl}, \mathrm{pH} 7.5$, and eluted with a linear gradient of $0.5 \mathrm{M}-\alpha$-methyl D-glucoside in equilibration buffer at $10 \mathrm{ml} \mathrm{h}^{-1}$ in the cold.

Analytical methods. For the determination of total phosphorus the method of Ames (1966) was used. Amino sugars and amino acids were quantitatively determined in hydrolysates $\left(4 \mathrm{M}-\mathrm{HCl}, 100^{\circ} \mathrm{C}, 16 \mathrm{~h}\right)$ using a Biotronic LC 6001 Amino Acid Analyzer. Amino sugars were also measured by the Elson-Morgan method (Johnson, 1971). Polyols, sugars and amino sugars were analysed and quantified by gas-liquid chromatography (GLC) as described by Albersheim et al. (1967). Glycerol, glucose, galactose and pyruvate were assayed enzymically (Bergmeyer, 1974). For determination of the anomeric configuration of glycosyl residues specific glycosidases were used under optimal reaction conditions. For chromium trioxide oxidation, carbohydrates and cell walls were treated with chromic oxide essentially as described by Hoffmann $e$ et al. (1972). Oxidative destruction of glycosyl residues was measured by GLC following acid hydrolysis $\left(2 \mathrm{M}-\mathrm{HCl}, 100^{\circ} \mathrm{C}, 3 \mathrm{~h}\right)$ of oxidized material, reduction $\left(\mathrm{NaBH}_{4}\right)$ and acetylation of sugar derivatives.

Chemicals. Enzymes and cosubstrates were purchased from Boehringer and Sigma. $\alpha$-Methyl D-glucoside was obtained from Sigma. All biochemicals used were of highest commercial purity available. 
Table 1. Composition of $H F$ hydrolysates obtained from cell walls of various $B$. linens strains, B. casei NCDO 2048 and B. epidermidis NCDO 2286

The $\mathrm{HF}$ hydrolysates were treated with $\mathrm{HCl}\left(2 \mathrm{M}, 100^{\circ} \mathrm{C}, 3 \mathrm{~h}\right)$; polyols and sugars were then determined qualitatively or quantitatively by GLC.

\begin{tabular}{|c|c|c|c|c|c|c|c|c|c|}
\hline \multirow[b]{2}{*}{ Strain } & \multicolumn{9}{|c|}{ Composition $\left[\mathrm{nmol}(\mathrm{mg} \text { cell wall })^{-1}\right]$} \\
\hline & $\begin{array}{l}\text { Phos- } \\
\text { phorus }\end{array}$ & $\begin{array}{l}\text { Gly- } \\
\text { cerol }\end{array}$ & $\begin{array}{l}\text { Rib- } \\
\text { itol }\end{array}$ & $\begin{array}{c}\text { Mann- } \\
\text { itol }\end{array}$ & $\begin{array}{l}\text { Glu- } \\
\text { cose }\end{array}$ & $\begin{array}{c}\text { Galac- } \\
\text { tose }\end{array}$ & $\begin{array}{c}\text { Rham- } \\
\text { nose }\end{array}$ & $\begin{array}{l}\text { Glucos- } \\
\text { amine }\end{array}$ & $\begin{array}{c}\text { Galactos- } \\
\text { amine }\end{array}$ \\
\hline \multicolumn{10}{|l|}{ B. casei } \\
\hline NCDO 2048 & 1400 & 780 & - & - & 640 & 140 & - & 420 & 140 \\
\hline \multicolumn{10}{|l|}{ B. epidermidis } \\
\hline NCDO 2286 & 1300 & 840 & - & 520 & - & 520 & - & 260 & - \\
\hline \multicolumn{10}{|l|}{ B. linens } \\
\hline $\mathrm{AC} 577$ & 600 & 370 & - & 170 & - & 90 & - & 90 & 40 \\
\hline $\mathrm{AC} 480$ & 910 & 350 & - & 700 & 160 & - & 320 & 40 & - \\
\hline \multicolumn{10}{|l|}{ B. linens ${ }^{*}$} \\
\hline $002,0101,0501,1501$ & + & + & - & - & + & + & - & + & + \\
\hline 1901 & + & + & - & - & + & - & - & - & + \\
\hline $1801, \mathrm{R} 70$ & + & + & - & - & + & + & - & + & - \\
\hline 1001,1401 & + & + & - & - & + & - & + & + & + \\
\hline 0010 & + & + & + & - & + & + & - & + & - \\
\hline $2101,3001,3101$ & + & + & + & - & + & - & - & - & + \\
\hline $\mathrm{R} 22$ & + & + & - & + & + & -- & - & + & - \\
\hline
\end{tabular}

RESULTS

Composition of the non-peptidoglycan moiety in the cell walls of B. casei, B. epidermidis and various strains of $B$. linens

By treating cell walls with $60 \%$ aqueous HF, phosphodiester-linked polymers are cleaved from the peptidoglycan and the phosphate-ester bonds in these polymers are hydrolysed (Anderson et al., 1977). The composition of HF hydrolysates obtained from cell walls of the various Brevibacterium species investigated is given in Table 1. As shown previously (Fiedler $e t$ al., 1981) the presence of the compounds listed is consistent with the occurrence of teichoic acids in the cell wall. The structural features of the teichoic acids of $B$. linens and $B$. iodinum and of $B$. case $i$ and $B$. epidermidis were different. In the cell wall of $B$. casei glycerol was the only polyol, but in the cell wall of $B$. epidermidis glycerol was present together with mannitol. Glycerophosphate units of the teichoic acid of $B$. casei were substituted by glucose and galactose as indicated by the occurrence of $\alpha$-D-glucopyranosyl-2-glycerol and $\alpha$-D-galactopyranosyl2-glycerol in the HF hydrolysates. Similarly, in the teichoic acid of B. epidermidis, more than half the total glycerol was cleaved by HF as $\alpha$-D-galactopyranosyl-2-glycerol. However, mannitol had no sugar residues as substituents at hydroxyl groups since no appropriate glycosides were detected in the HF hydrolysates (data not shown). That glycerol and mannitol co-exist in cell walls of various strains of $B$. iodinum and $B$. linens was suggested by the work of Fiedler $e t$ al. (1981) and of Anderton \& Wilkinson (1985). To clarify this suggestion the $B$. linens strains AC480 and AC577 were investigated in more detail.

\section{Chemical characteristics of teichoic acids from B. linens strains AC480 and AC577}

Chromatography on DEAE-Sephacel of solubilized teichoic acids from $B$. linens strains AC480 and AC577 yielded single peaks in both cases (Fig. 1). Gel filtration of the material corresponding to these peaks on Sephacryl S-300 resulted in the separation into two fractions of the material from AC577, whereas only one fraction was obtained in the case of AC480 (Fig. 2). The results of analysis of these fractions are shown in Table 2. They clearly indicate the existence of a glycerol teichoic acid with galactose and glucosamine as substituents corresponding to fraction I of AC577. The mannitol teichoic acid present in fraction II of AC577 and in the only fraction of AC480 contained glycerol and sugar residues. 


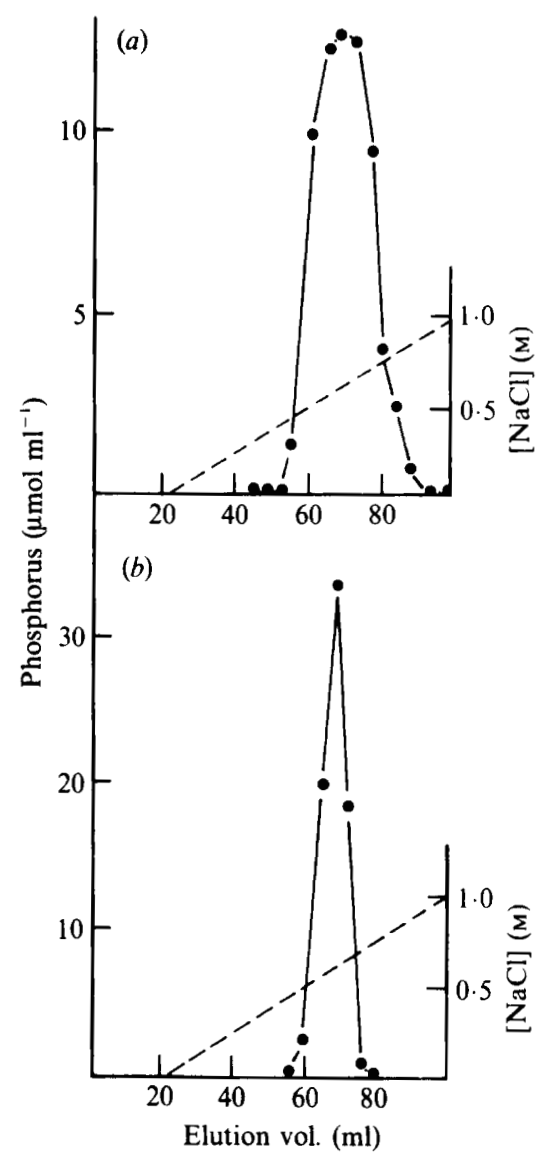

Fig. 1

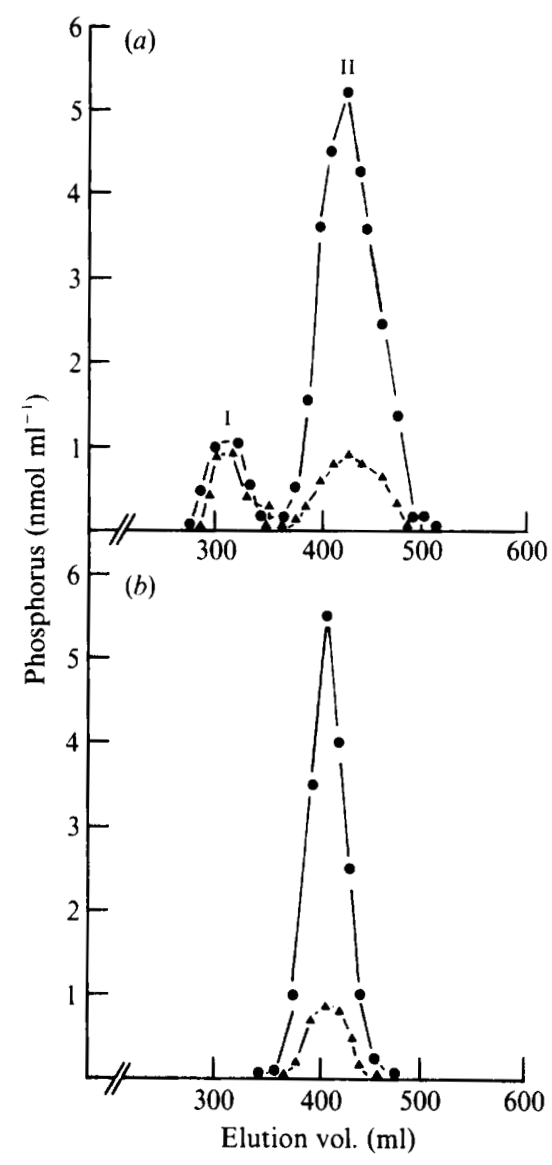

Fig. 2

Fig. 1. Chromatography on DEAE-Sephacel of teichoic acids extracted from cell walls of $B$. linens strains AC577 (a) and AC480 (b). Fractions $(2 \mathrm{ml})$ were collected and analysed for phosphorus.

Fig. 2. Gel-filtration on Sephacryl S-300 of teichoic acids from B. linens strains AC577 (a) and AC480 (b) partially purified by ion-exchange chromatography (Fig. 1). Fractions $(4 \mathrm{ml})$ were collected and analysed for phosphorus $(\bullet)$ and glycerol $(\boldsymbol{A})$. Glycerol was determined after HF treatment of samples followed by hydrolysis with $\mathrm{HCl}\left(2 \mathrm{M}, 100^{\circ} \mathrm{C}, 3 \mathrm{~h}\right)$.

Table 2. Composition of fractions obtained by gel-filtration chromatography of teichoic acids from B. linens strains AC577 and AC480

\begin{tabular}{|c|c|c|c|c|c|c|c|c|}
\hline \multirow[b]{2}{*}{ Strain } & \multirow[b]{2}{*}{ Fraction* } & \multicolumn{7}{|c|}{ Molar ratio to phosphorus } \\
\hline & & $\begin{array}{l}\text { Gly* } \\
\text { cerol† }\end{array}$ & $\begin{array}{c}\text { Mann- } \\
\text { itol+ }\end{array}$ & $\begin{array}{l}\text { Glu- } \\
\text { coset }\end{array}$ & $\begin{array}{l}\text { Galac- } \\
\text { tose† }\end{array}$ & $\begin{array}{c}\text { Rham- } \\
\text { nosef }\end{array}$ & $\begin{array}{l}\text { Glucos- } \\
\text { amine }\end{array}$ & $\begin{array}{c}\text { Galactos- } \\
\text { amine }\end{array}$ \\
\hline AC577 & I & 1.0 & - & - & 0.7 & - & 0.9 & - \\
\hline AC577 & II & $0 \cdot 2$ & 0.7 & - & - & - & $0 \cdot 1$ & $0 \cdot 1$ \\
\hline $\mathrm{AC} 480$ & & 0.4 & 0.8 & $0 \cdot 2$ & - & 0.8 & $0 \cdot 1$ & - \\
\hline
\end{tabular}

* See Fig. 2.

+ Enzymic assay.

$¥$ Measurement by GLC.

$\S$ Quantified colorimetrically and by use of an Amino Acid Analyzer. 


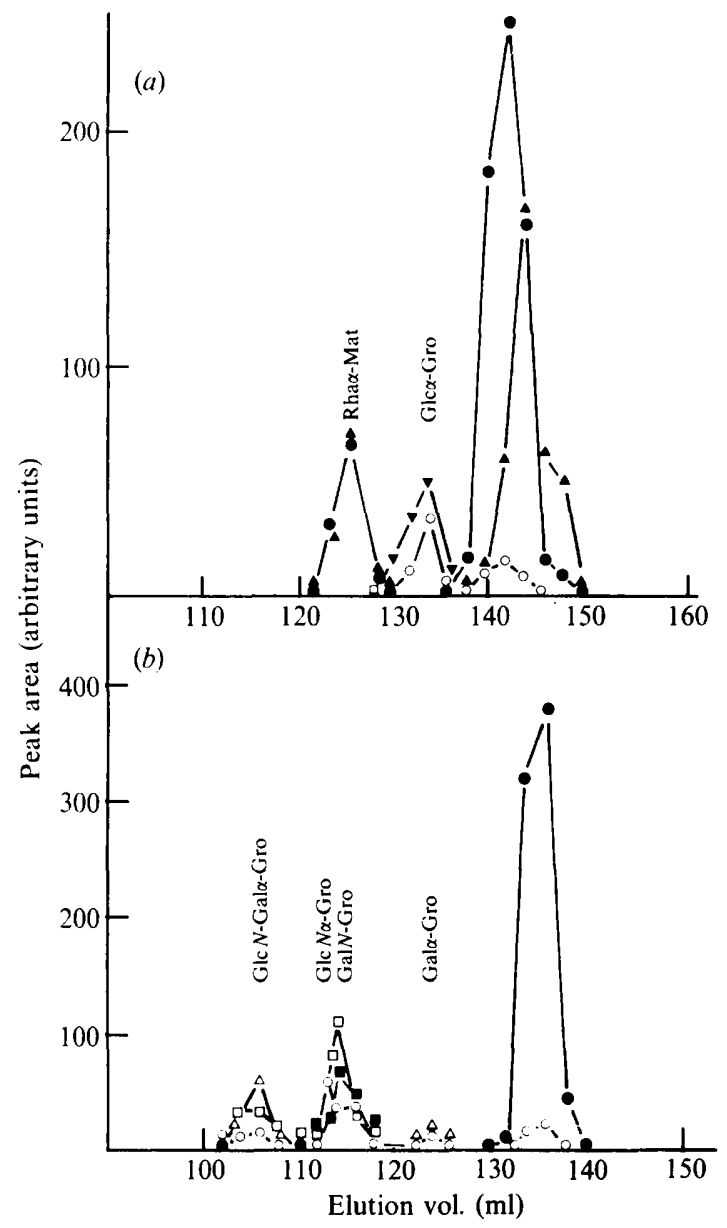

Fig. 3. Gel-filtration chromatography on Bio-Gel P2 of HF hydrolysates of cell walls of $B$. linens strains $\mathrm{AC} 480(a)$ and $\mathrm{AC} 577(b)$. The composition of fractions was determined by GLC after hydrolysis with $\mathrm{HCl}\left(2 \mathrm{M}, 100^{\circ} \mathrm{C}, 3 \mathrm{~h}\right)$; peak areas monitored are given. The structural features of glycosides were determined in separate experiments. - Mannitol; $O$, glycerol; $\boldsymbol{\Delta}$, rhamnose; $\Delta$, galactose; $\square$, glucosamine; $\boldsymbol{\square}$, galactosamine; $\mathbf{\nabla}$, glucose. Gal, galactosyl; Gal $N$, galactosaminyl; Glc $N$, glucosaminyl; Glc, glucosyl; Gro, glycerol; Mat, mannitol; Rha, rhamnosyl.

Structural features of teichoic acids from B. linens strains AC480 and AC577

To obtain structural information on the teichoic acids, HF hydrolysates of cell walls and of separated polymers were analysed. The water-soluble degradation products representing dephosphorylated repeating units of teichoic acid chains were fractionated on a Bio-Gel P2 column. As shown in Fig. 3 mannitol and glycerol (close to the total fluid volume of the column) were separated from glycosides which eluted earlier owing to their larger effective molecular sizes. Compositions were determined by GLC after hydrolysis $\left(2 \mathrm{M}-\mathrm{HCl}, 10{ }^{\circ} \mathrm{C}, 3 \mathrm{~h}\right)$ of the samples. Structural data for the glycosides obtained from several separate experiments (quantitative determination of constituents, enzymic cleavage of glycoside linkages using specific glycosidases, GLC of glycosides, chromic oxide oxidation, reaction with ninhydrin) are shown in Fig. 3. In strain AC577 the major teichoic acid corresponds to a poly(mannitol phosphate) without any sugar substituents. However, in AC480 the mannitol teichoic acid carries rhamnosyl substituents which appear to be $\alpha$-glycosidically linked (resistance to chromic oxide oxidation) to many mannitol phosphate units. The additional glycerol teichoic acid in AC577 had glycerophosphate units that were primarily substituted with $\mathrm{N}$-acetylglucosaminyl- 


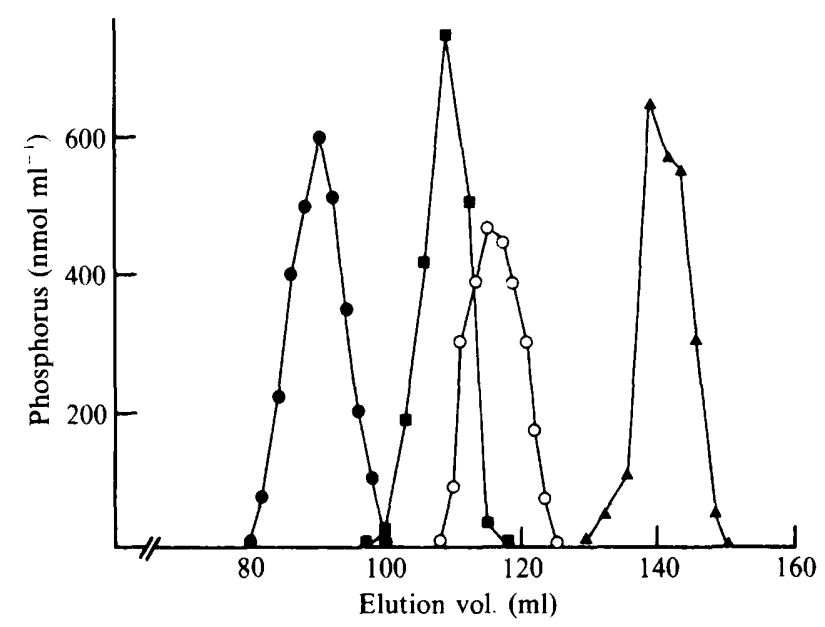

Fig. 4. Gel-filtration chromatography on Sepharose 6B-CL of glycerophosphate-containing material obtained after Smith degradation of $B$. linens strain AC577 fraction II (Fig. 2). Polyglycerophosphate teichnoic acids and deacylated cardiolipin were used as markers. $O$, Glycerophosphate-containing compound resistant to Smith degradation; $\bullet$, glycerol teichoic acid corresponding to fraction I (Fig. 2); $\mathbf{\square}$, polyglycerophosphate teichoic acid isolated from cell walls of Bacillus pumilus; $\boldsymbol{\Delta}$, deacylated cardiolipin.

galactosyl dimers and to a rather small extent with galactosyl residues. The glycerol co-fractionating with the mannitol teichoic acids in gel-filtration chromatography (Fig. 2) corresponded to the remaining fractions in Fig. 3 (separate fractionation not shown). It became apparent that these glycerol moieties are also linked via phosphodiester bonds and are substituted with different glycosyl residues. In AC577 substitution was with $\alpha$ - $N$-acetylglucosaminyl and $N$-acetylgalactosaminyl residues, and in AC480 $\alpha$-glucosyl-glycerol was found.

Structural organization of glycerol co-fractionating with mannitol teichoic acids

To elucidate the structural role of the glycerol that co-fractionated with mannitol teichoic acids on column chromatography, the fractions corresponding to the peaks in Fig. 2 were subjected to Smith degradation. Subsequent gel filtration (Sephadex G-25) of the oxidation products yielded unidentified phosphate-containing degradation compounds in the inclusion volume of the column and glycerophosphate-containing material [equimolar glycerol and phosphorus after hydrolysis $\left.\left(4 \mathrm{M}-\mathrm{HCl}, 100^{\circ} \mathrm{C}, 3 \mathrm{~h}\right)\right]$ at the exclusion volume of the column (data not shown). To investigate the polymeric nature of the glycerophosphate the corresponding fraction was refractionated on a Sepharose $6 \mathrm{~B}-\mathrm{CL}$ column. In separate experiments compounds of different effective molecular sizes were used as markers. As shown in Fig. 4 the glycerophosphate-containing compound of strain AC577 that was resistant to Smith degradation was similar in size to the polyglycerophosphate of Bacillus pumilus (Kusser \& Fiedler, 1983) and differed both from the larger $\alpha$-N-acetylglucosaminyl-galactosyl-substituted glycerol teichoic acid of AC577 and from the significantly smaller deacylated cardiolipin. A similar result was obtained using the corresponding fraction from AC480. Hence, the glycerol moieties that elute after the mannitol teichoic acids in gel-filtration chromatography obviously correspond to sugar-substituted polyglycerophosphate entities. Whether these have a structural relationship to the mannitol teichoic acid was studied in the case of AC 480 by ConA affinitychromatography. From teichoic acids, and from lysozyme- and amidase-treated teichoic-acidlinked glycopeptides, only the $\alpha$-glucosyl-substituted polyglycerophosphate bound to the Con $\mathrm{A}-$ Sepharose column and was subsequently released by $\alpha$-methylglucoside (Fig. 5). Since mannitol teichoic acid was separated from the $\alpha$-glucosyl-substituted polyglycerophosphate in these experiments the latter was recognized to be an independent polymer in the cell wall of strain 


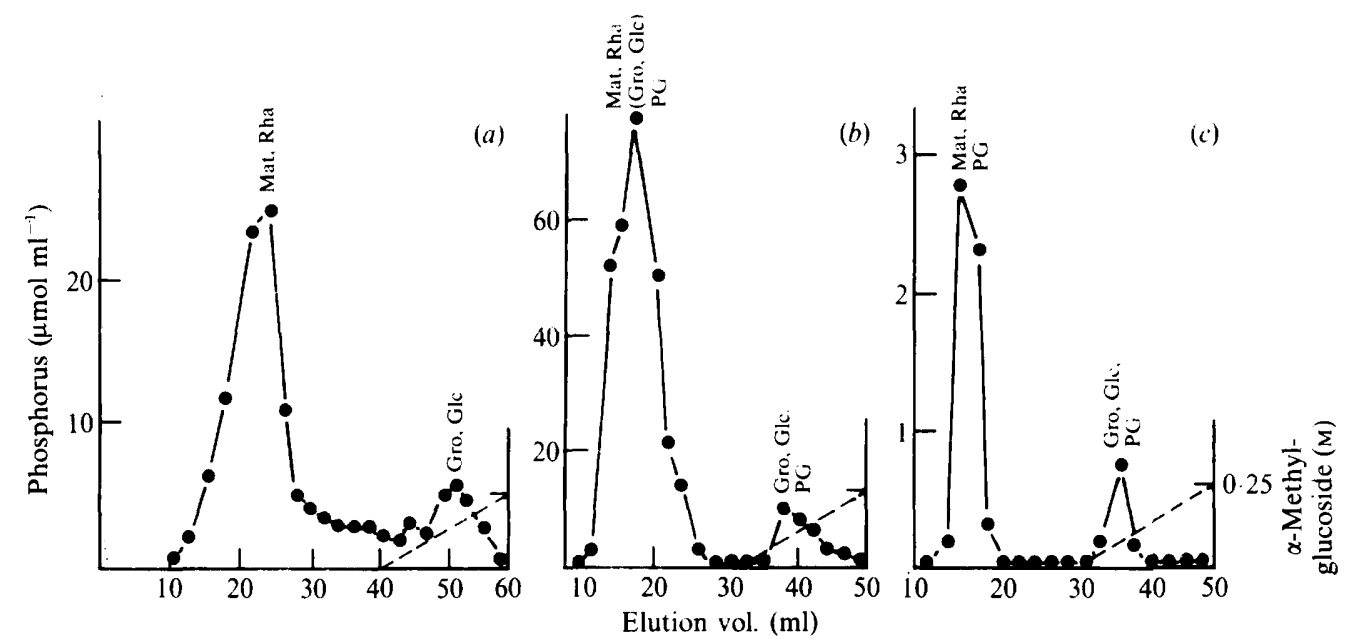

Fig. 5. ConA -Sepharose affinity chromatography of different teichoic acid preparations from cell wall of $B$. linens strain AC 480. Phosphorus was measured in the fractions indicated. The other constituents were determined in pooled fractions by GLC and by use of an Amino Acid Analyzer. (a) Teichoic acid routinely extracted from cell walls; $(b)$ teichoic-acid-linked glycopeptide prepared by digestion of cell walls with lysozyme; $(c)$ teichoic-acid-peptidoglycan complex prepared by digestion of $(b)$ with amidase. Glc, glucose; Gro, glycerol, Mat, mannitol; Rha, rhamnose; PG, peptidoglycan fragments.

AC480. It is suggested that the same is true for strain AC577 although its $N$-acetylglucosamineand $\mathrm{N}$-acetylgalactosamine-substituted glycerol teichoic acid did not bind to wheat-germ lectin or to Helix pomatia lectin Sepharose columns. Hence, these organisms have both glycerol teichoic acid as well as mannitol teichoic acid as separate cell wall components.

\section{DISCUSSION}

The data presented, together with earlier findings (Fiedler et al., 1981, Anderton \& Wilkinson, 1985), indicate that B. casei NCDO 2048 and B. epidermidis NCDO 2286 (Collins et $a l ., 1983)$ possess teichoic acids as the dominant anionic polymers in their cell walls. However, the structural features of the teichoic acids occurring in these two species are different. In $B$. case $i$ the teichoic acid is the classical type of glycerol teichoic acid in which glycerol residues are joined by phosphodiester bonds between C-1 and C-3 of adjacent units (Archibald \& Baddiley, 1966). Glycerol residues are substituted at the hydroxyl of C-2 by $\alpha$-linked glucopyranosyl or galactopyranosyl residues. In $B$. epidermidis there is a similar structural entity in which the glycerophosphate units are partially substituted only by galactosyl residues. Contrary to the findings of Anderton \& Wilkinson (1985) with $B$. epidermidis strain 2285 , a further polymeric unit was recognized in B. epidermidis NCDO 2286 corresponding to the mannitol teichoic acid described for $B$. iodinum (Anderton \& Wilkinson, 1980) and several strains of $B$. linens (Fiedler et al., 1981). The backbone of the polymer is assumed, by analogy with the results of Anderton \& Wilkinson (1985), to be a poly(D-mannitol phosphate) containing 1-6 phosphodiester linkages. The mannitol residues do not appear to be substituted with sugar residues. We did not investigate whether there is a structural connection between the poly(mannitol phosphate) and the polyglycerophosphate entities; neither is it clear whether the differently substituted glycerol residues liberated from cell walls of $B$. casei on treatment with HF belong to the same polymer or constitute separate chains with one type of substituent each. We did not investigate whether all the sugar components detected in the HF hydrolysates were constituents of the teichoic acids or belonged to other entities, e.g. $\operatorname{poly}(N$-acetylglucosaminyl phosphate) or poly ( $N$-acetylgalactosaminyl phosphate) (Fiedler \& Schäffler, 1987); nor did we look for the existence of other substituents, e.g. acetyl and pyruvyl residues. However, our results 
tentatively indicate that D-alanyl substitution, both of glycerol and of mannitol residues, is absent in these teichoic acids (data not shown).

The structural features of the teichoic acids of $B$. case $i$ and $B$. epidermidis and the composition of teichoic acids of recent isolates of $B$. linens (Seiler, 1986) correspond to the earlier findings for a large number of $B$. linens and related strains (Fiedler et al., 1981). Thus, the genus Brevibacterium exhibits homogeneity with respect to the occurrence of teichoic acids in cell walls. However, as noted by Fiedler et al. (1981) for $B$. linens strains, the chemical structure of the cell wall teichoic acids does not unambiguously differentiate between the species. Because the teichoic acids are phenotypically stable, the structural features of these compounds may be used to describe strains. More importantly, the presence of cell wall teichoic acids can be used as an additional chemotaxonomic marker for the allocation of Gram-positive bacteria to Brevibacterium.

Although the co-existence of a glycerol and a ribitol teichoic acid in the cell wall is wellestablished for Staphylococcus xylosus DSM 20266, Staphylococcus saprophyticus CCM 883 and Micrococcus sp. 24 (Fiedler \& Steber, 1984; Endl et al., 1983; Archibald \& Heptinstall, 1971), this was previously merely assumed for strains of Brevibacterium on the basis of the qualitative and quantitative data available (Fiedler et al., 1971; Anderton \& Wilkinson, 1980). Our data clearly demonstrate that in both B. linens AC480 and AC577, mannitol teichoic acids and differently substituted glycerol teichoic acids occur as structurally separate polymers. This was most convincingly established by affinity chromatography using ConA-Sepharose of teichoicacid-peptidoglycan complexes prepared by digestion of cell walls of AC480 with lysozyme and subsequent treatment of these lysates with $N$-acetylmuramyl-(L-alanine) amidase. The preparations were separated into a binding fraction containing all the $\alpha$-glucosyl-substituted polyglycerophosphate and a non-binding fraction containing mannitol and rhamnose without glycerol. Thus, the separation of extracted teichoic acids using ConA-Sepharose chromatography is not an artifact due to the cleavage of structural entities in the course of the extraction from cell walls.

Whereas the mannitol teichoic acid in AC577 appeared to be without any sugar substituent that of AC480 had $\alpha$-glycosidically linked rhamnosyl residues. Since rhamnose could be liberated by acid treatment $\left(0.01 \mathrm{M}-\mathrm{HCl}, 100^{\circ} \mathrm{C}, 1 \mathrm{~h}\right)$ without hydrolysis of the polymer (unpublished data) rhamnose is not involved in forming the chain. Thus, in both AC577 and AC480 the mannitol teichoic acids correspond to poly(mannitol phosphate). We assume that this structural characteristic is in keeping with the poly(D-mannitol phosphate)-containing 1-6 phosphodiester linkages described for $B$. iodinum (Anderton \& Wilkinson, 1985). The rhamnosyl residues can be attached to the poly(mannitol phosphate) chain at the four hydroxyl groups (C-2 to C-5) of each mannitol phosphate unit. However, we have no data on which hydroxyl is structurally preferred by the enzyme transferring rhamnosyl residues in the course of the biosynthesis of the polymers. This question is of interest because of the structural symmetry of mannitol and mannitol diphosphate. We also do not know whether rhamnosyl residues of the poly(mannitol phosphate) of AC480 are present only as monomers or also as dimers as found in Listeria monocytogenes (Fiedler et al., 1984). Our data indirectly support the suggestion that ribitol teichoic acids may occur as separate polymers together with glycerol teichoic acids in certain strains of Brevibacterium. Many other questions remain open. What is the function of these different teichoic acids within the cell walls? How are they distributed? How is their biosynthesis regulated during growth? In an evolutionary context one may ask why in cell walls of certain strains of Brevibacterium glycerol teichoic acids occur together with ribitol or mannitol teichoic acids, whereas ribitol teichoic acids obviously do not co-exist with mannitol teichoic acids. In the light of the known phylogeny of Gram-positive bacteria it seems remarkable that in genera of both branches of descent (Stackebrandt \& Woese, 1981) teichoic acids with common structural and biosynthetic features (unpublished data) are present in cell walls. Although these polymers are sometimes thought to be without physiological significance it is interesting to speculate on why these structural entities, requiring a huge enzymic machinery and consequently a series of genes, exist among bacteria of completely diverse phylogeny. 
We are grateful to Dr H. Seiler, Dairy Research Institute of Weihenstephan, D-8050 Freising, FRG, for providing $B$. linens isolates from cheese and we thank Dr J.-V. Höltje, Max-Planck-Institut für Entwicklungsbiologie, D-7400 Tübingen, FRG, for the $N$-acetylmuramyl-(L-alanine) amidase sample from human serum.

\section{REFERENCES}

Albersheim, P., Nevius, D. J., English, P. D. \& KARR, A. (1967). A method for the analysis of sugars in plant cell wall polysaccharides by gas-liquid chromatography. Carbohydrate Research 5, 340-345.

AMES, B. W. (1966). Assay of inorganic phosphate, total phosphate and phosphatases. Methods in Enzymology 8, 115-118.

Anderson, A. J., Green, R. S. \& Archibald, A. R. (1977). Specific determination of ribitol teichoic acid in whole bacteria and isolated walls of Bacillus subtilis W23. Carbohydrate Research 57, c7-c10.

ANDERTON, W. J. \& Wilkinson, S. G. (1980). Evidence for the presence of a new class of teichoic acid in the cell walls of bacterium NCTC 9742. Journal of General Microbiology 118, 343-351.

ANDERToN, W. J. \& Wilkinson, S. G. (1985). Structural studies of a mannitol teichoic acid from the cell walls of bacterium NCTC 9742 . Biochemical Journal 226, 587-599.

ARChibald, A. R. \& BADDILEY, J. (1966). The teichoic acids. Advances in Carbohydrate Chemistry 21, 323-375.

ARChibald, A. R. \& Heptinstall, S. (1971). The teichoic acids of Micrococcus sp. 24. Biochemical Journal 125, 361-363.

BERGMEYER, H. U. (1974). Methoden der enzymatischen Analyse. Weinheim: Verlag Chemie.

Bousfield, J. J. (1972). A taxonomic study of some coryneform bacteria. Journal of General Microbiology 71, 441-455.

BREED, R. S. (1953). The Brevibacteriaceae fam. nov. of the order Eubacteriales. Riass Communicazione, VI Congress of International Microbiology, Roma 1, 13-14.

BREED, R. S. (1957). Brevibacteriaceae. In Bergey's Manual of Determinative Bacteriology, 7th edn, pp. 490-505. Edited by R. S. Breed, E. G. D. Murray \& N. R. Smith. Baltimore: Williams \& Wilkins.

Collins, M. D., Goodfellow, M. \& Minnikin, D. E. (1979). Isoprenoid quinones in the classification of coryneform and related bacteria. Journal of General Microbiology 110, 127-136.

Collins, M. D., Jones, D., Keddie, R. M. \& SNeath, P. H. A. (1980). Reclassification of Chromobacterium iodinum (Davis) in a redefined genus Brevibacterium (Breed) as Brevibacterium iodinum nom. rev.; comb. nov. Journal of General Microbiology 120, 1-10.

Collins, M. D., Farrow, J. A. E., Goodfellow, M. \& MINNIKIN, D. E. (1983). Brevibacterium casei $\mathrm{sp}$. nov. and Brevibacterium epidermidis sp. nov. Systematic and Applied Microbiology 4, 388-395.

Crombach, W. H. J. (1974). Relationship among coryneform bacteria from soil, cheese and sea fish. Antonie van Leeuwenhoek 40, 347-359.

Da Silva, G. A. N. \& Holt, J. (1965). Numerical taxonomy of certain coryneform bacteria. Journal of Bacteriology 90, 921-927.
Davis, G. H. G. \& Newton, K. G. (1969). Numerical taxonomy of some named coryneform bacteria. Journal of General Microbiology 56, 195-214.

Endl, J., Seidl, H. P., Fiedler, F. \& Schleifer, K. H. (1983). Chemical composition and structure of cell wall teichoic acids of staphylococci. Archives of Microbiology 135, 215-223.

FIEDLER, F. \& SCHÄFFLER, M. J. (1987). Teichoic acids in cell walls of strains of the 'nicotianae' group of Arthrobacter: a chemotaxonomic marker. Systematic and Applied Microbiology 9, 16-21.

FIEDleR, F. \& STEBer, J. (1984). Structure and biosynthesis of teichoic acids in the cell walls of Staphylococcus xylosus DSM 20266. Archives of Microbiology 138, 321-328.

Fiedler, F., Schleifer, K. H., Cziharz, B., INTERSCHICK, E. \& KANDLER, O. (1970). Murein types in Arthrobacter, brevibacteria, corynebacteria and microbacteria. Publications de la Faculté des sciences de l'Université J. E. Purkyne Brno 47, 111-122.

Fiedler, F., SchÄffler, M. J. \& Stackebrandt, E. (1981). Biochemical and nucleic acid hybridization studies on Brevibacterium linens and related strains. Archives of Microbiology 129, 85-93.

Fiedler, F., Seger, J., SchrettenbrunNer, A. \& SeEliger, H. P. R. (1984). The biochemistry of murein and cell wall teichoic acids in the genus Listeria. Systematic and Applied Microbiology 5, 360-376.

HoffmanN, J., LindberG, B. \& Svenson, S. (1972). Determination of sugar residues in acetylated oligoand polysaccharides by oxidation with chromium trioxide in acetic acid. Acta chemica scandinavica 26, 661-664.

JoHnson, A. R. (1971). Improved method of hexosamine determination. Analytical Biochemistry 44, 628-635.

JONES, D. (1975). A numerical taxonomic study of coryneform and related bacteria. Journal of General Microbiology 87, 52-96.

KAYA, S., ARAKI, Y. \& ITO, E. (1985). Characterization of a novel linkage unit between ribitol teichoic acid and peptidoglycan in Listeria monocytogenes cell walls. European Journal of Biochemistry 146, 517-522.

KedDIE, R. M. \& CURE, L. (1977). The cell wall composition and distribution of free mycolic acid in some named strains of coryneform bacteria and in isolates from various natural sources. Journal of Applied Bacteriology 42, 229-252.

KOCH, H. U. \& Fischer, W. (1978). Acyldiglycosyldiacylglycerol-containing lipoteichoic acid with a poly(3-O-galabiosyl-2-O-galactosyl-sn-glycero-1phosphate) chain from Streptococcus lactis Kiel 42172. Biochemistry 17, 5275-5281.

KoJima, N., ARAKI, Y. \& ITo, E. (1985). Structure of the linkage units between ribitol teichoic acids and 
peptidoglycan. Journal of Bacteriology 161, 299-306.

KuSSER, W. \& FiEdLER, F. (1983). Teichoicase from Bacillus subtilis Marburg. Journal of Bacteriology 155, 302-310.

Mollner, S. \& Braun, V. (1984). Murein hydrolase ( $N$-acetylmuramyl-L-alanine-amidase) in human serum. Archives of Microbiology 140, 171-177.

SCHLEIFER, K. H. \& KANDLER, O. (1967). Zur chemischen Zusammensetzung der Zellwände der Streptokokken, I. Zur Aminosäuresequenz des Mureins von Str. thermophilus and Str. faecalis. Archiv für Mikrobiologie 57, 335-365.

SEILER, H. (1986). Identification of cheese-smear coryneform bacteria. Journal of Dairy Research 53, 439-449.

SeIler, H., OHMEyer, G. \& BUSSE, M. (1977). Taxonomische Untersuchungen an Gram-positiven coryneformen Bakterien unter Verwendung eines VED-Programms zur Berechnung von Vernetzungsdiagrammen. Zentralblatt für Bakteriologie, Parasitenkunde, Infektionskrankheiten und Hygiene (Abteilung I, Originalreihe A) 238, 475-488.
Stackebrandt, E. \& Fiedler, F. (1979). DNA-DNA homology studies among strains of Arthrobacter and Brevibacterium. Archives of Microbiology 120, 289-295.

Stackebrandt, E. \& Woese, C. R. (1981). The evolution of the prokaryotes. Symposia of the Society for General Microbiology 32, 1-31.

Stackebrandt, E., Lewis, B. J. \& Woese, C. R. (1980). The phylogenetic structure of the coryneform group of bacteria. Zentralblatt für Bakteriologie, Parasitenkunde, Infektionskrankheiten und Hygiene (Abteilung I, Originalreihe C) 101, 137-149.

Yamada, K. \& Komagata, K. (1970). Taxonomic studies on coryneform bacteria. III. DNA base composition of coryneform bacteria. Journal of General and Applied Microbiology 16, 215-224.

Yamada, K. \& Komagata, K. (1972). Taxonomic studies on coryneform bacteria. IV. Morphological, cultural, biochemical and physiological characteristics. Journal of General and Applied Microbiology 18, 399-416. 